\title{
ROAD-CLIMATE ZONING FOR WATER-THERMAL MODE REGULATION IN TRANSPORT STRUCTURES
}

\author{
${ }^{1}$ Associate Professor Olena Usichenko \\ ${ }^{2}$ Alina Kvatadze \\ ${ }^{1}$ Ukraine, Kyiv, National Transport University, \\ Professor of Transport Construction and Property Management Department; \\ ${ }^{2}$ Ukraine, Kyiv, State Road Agency of Ukraine, \\ Senior Specialist of the Department Intelligent Transport Systems
}

DOI: https://doi.org/10.31435/rsglobal_ws/31032020/6966

\section{ARTICLE INFO}

Received: 17 January 2020

Accepted: 20 March 2020

Published: 31 March 2020

\section{KEYWORDS}

Wet-thermal regime, road-climate zone,

cluster analysis of indicators.

\begin{abstract}
The article considers the problems of road-climatic zoning of the territory of Ukraine. The shortcomings of the existing system and the need to update and improve it were justified. The purpose of work was formed and realized taking into account modern approaches to meteorological data processing and segmentation methods. The study is based on long-term observations of weather conditions throughout the country. Using the moisture-thermal regime calculation and analytical system, the collected static meteorological information was processed and tables of the initial data for further analytical processing were obtained. The paper describes the methodology of cluster analysis using as the main tool for the typification of territories and the allocation of morphologically homogeneous humid areas. The result of the work was the elaboration of a road and climatic zoning map under the wetting conditions of the road subgrade working layer.
\end{abstract}

Citation: Olena Usichenko, Alina Kvatadze. (2020) Road-Climate Zoning for Water-Thermal Mode Regulation in Transport Structures. World Science. 3(55), Vol.1. doi: 10.31435/rsglobal_ws/31032020/6966

Copyright: (C) 2020 Olena Usichenko, Alina Kvatadze. This is an open-access article distributed under the terms of the Creative Commons Attribution License (CC BY). The use, distribution or reproduction in other forums is permitted, provided the original author(s) or licensor are credited and that the original publication in this journal is cited, in accordance with accepted academic practice. No use, distribution or reproduction is permitted which does not comply with these terms.

Introduction. The need to improve road-climatic zoning and to develop recommendations on the application of climatic characteristics and climatic zoning of the territory of Ukraine for road construction is due to the fact that these issues were developed back in 70-80 years of the last century using data on climatic conditions throughout the territory of the former USSR. Global climate change (warming) on the planet has changed the amount of atmospheric humidity. As a consequence, the elements of the road structure are subject to increased precipitation effects, which leads to a change of the whole structure waterthermal regime (WTR). Moistening of the road structure is the main cause of destruction and deformation. Approaches to the design of WTR regulation structures should vary according to the external influences intensity. Drainage systems designing requires to updating, methodological regulation, taking into account the modern meteorological information, and obtaining special meteorological values databases that are estimated value in road construction elements designing procedure.

The problems of the recent years changes climatic factors influence on the road construction based on meteorological data of the Lithuanian Hydrometeorological Service (LHS) were reflected in the climatic zoning of the Republic of Lithuania territory in $[1,2]$. The grouping of precipitation by their level using statistical methods and based on cluster analysis for the Poland temperate climate is presented in [3].

The important role of clustering as a convenient and accurate method for data segmentation and analytics has been analyzed in [4]. According to the cluster analysis algorithm, using a map of different spatial data sets and software capabilities, a map with selected homogeneous hydrological zones was constructed [5]. 
Research results. Currently, the valid regulatory document setting the climatic parameters for the design of civic, industrial buildings and structures, heating, ventilation, air conditioning, water supply, in the planning and construction of urban and rural settlements is DSTU-N B V.1.1-27:2010. The available data are insufficient for road-climatic zoning, as only average rainfall values are provided for regions. However, soil and hydrological conditions and freezing depth are not taken into account, although it is one of the most important climatic indicators in road climatology. In view of the above, the purpose of the study was formulated: to develop a map of road and climatic zoning of the Ukraine territory under conditions of wetting with atmospheric precipitation on the basis of climate zoning methods.

Zoning is a complex process as it takes into account not only the elements of climate, hydrology and soil conditions. Road-climatic zoning of the Ukraine territory is enshrined in DBN B.2.3-4 2015 "Highways" and differentiates the norms of transport structures designing and construction. According to landscape-geographical zoning, soil-hydrologic and wetting conditions, as well as experience of road operation, the territory of Ukraine is divided into four climatic zones: northern, central, southern and mountainous. It should be noted that the existing road-climate zoning reflects only the general dependence of road design and construction on climate and most other natural conditions, and is therefore schematic. In the process of road designing, it is important not to limit the general characteristics of the climatic conditions obtained by assigning the area of the route to the relevant zone, but to study with sufficient detail the climate elements according to the data of local meteorological stations.

In order to improve the normative support and to form the meteorological characteristics databases for WTR regulation structure design needs the methods of meteorological information processing, existing meteorological data were analyzed and generalized, the analysis and estimation of the statistical meteorological information required volume were carried out. On the basis of the analysis, the collection of statistical meteorological information for ten years at thirty-eight meteorological stations of Ukraine was performed, and the obtained meteorological data sets were analyzed. Using the available calculation and analytical system, the statistical processing of the obtained arrays of meteorological information was performed. In the process of developing a methodology of climatic characteristics application for the construction needs, the shortcomings of the calculation and analytical system (WTR) used for statistical processing of meteorological information were identified. The calculation apparatus was brought to the required level and the information base was updated.

Results and Discussion. Road-climatic zoning takes into account not only the natural and climatic characteristic, but also the features of road construction and maintenance. The basis of road-climatic zoning should be based on the distribution of heat and moisture - the wet-thermal regime of the terrain.

Based on collected data from meteorological stations (Askaniya-Nova, Berdyansk, Bila Tserkva, Bolhrad, Vinnytsya, Dnipropetrovsk, Donetsk, Druzhba, Zhytomyr, Zaporizhia, Kerch, Kyiv, Kirovohrad, Kovel, Lubny, Luhansk, Lutsk, Lviv, Melitopol, Mykolayiv, Mizhhirya, Ovruch, Odesa, Pervomaysk, Poltava, Pryluky, Rivne, Simferopol, Sumy, Ternopil, Uzhhorod, Uman, Kharkiv, Kherson, Khmelnytskyi, Cherkasy, Chernivtsi, Chernihiv) climatological characteristics of precipitation, snow cover and air temperature were analyzed, tables of data on average and extreme values were calculated and formed. By means of the calculation and analytical system "WTR" graphs of temperature course for a ten-year period and periods of wet-thermal regime of road construction have been developed. The snippet of the program window is shown in Fig. 1.

\begin{tabular}{|c|c|c|c|c|c|c|c|c|c|c|c|c|c|c|c|c|c|}
\hline $\begin{array}{c}\text { РІК } \\
\text { РОЗРАХХНКУ }\end{array}$ & 1 & 2 & 3 & 4 & 5 & 6 & 7 & 8 & 9 & 10 & 11 & 12 & $\begin{array}{c}\text { ПОЧАТОК } \\
\text { ВЕСНЯНОГО } \\
\text { РОЗРАХУНКОВ } \\
\text { ОГО ПЕРІОДУ- } \\
\text { Перехід через } \\
0\end{array}$ & $\begin{array}{c}\text { ПОЧАТОК } \\
\text { ОСІнНьОГО } \\
\text { РОЗРАХУНКОВОГо } \\
\text { ПЕРІОДУ - перехід } \\
\text { температури } \\
\text { через }+10\end{array}$ & $\begin{array}{c}\text { ПОЧАТОК } \\
\text { ЗИМОВОГО } \\
\text { РОЗРАХУНКОВОГ } \\
\text { О ПЕРІОДУ - } \\
\text { ПреХід Через -5 }\end{array}$ & $\begin{array}{c}\text { Період } \\
\text { замерзання } \\
\text {, доба }\end{array}$ & $\begin{array}{c}\text { ПОЧАТОК } \\
\text { ЛІТНЬОГО } \\
\text { РОЗРАХУНКОВ } \\
\text { ОГО ПЕРІОДУ - } \\
\text { КінецЬ } \\
\text { розмерзання }\end{array}$ \\
\hline 2006 & $-8,2$ & $-8,0$ & $-1,7$ & 8,4 & 13,7 & 18,0 & 20,1 & 19,2 & 14,6 & 8,6 & 2,1 & 1,7 & 18.03.2006 & 10.10 .2006 & 01.01 .2006 & 76 & 26.04 .2006 \\
\hline 2009 & $-4,5$ & $-3,0$ & 1,3 & 9,6 & 14,1 & 19,2 & 20,6 & 17,8 & 16,2 & 7,8 & 4,0 & $-4,6$ & & 07.10 .2009 & & 0 & 15.04 .2009 \\
\hline 2010 & $-11,0$ & $-4,4$ & $-0,5$ & 9,1 & 17,1 & 21,1 & 24,3 & 23,4 & 13,9 & 5,4 & 6,3 & $-5,3$ & 16.03 .2010 & 28.09 .2010 & 17.12 .2009 & 89 & 21.04 .2010 \\
\hline 2011 & $-3,7$ & $-7,8$ & $-0,5$ & 9,0 & 15,8 & 20,2 & 21,4 & 18,5 & 14,0 & 6,6 & 1,7 & 1,3 & 17.03 .2011 & 02.10 .2011 & 14.12 .2010 & 93 & 23.04 .2011 \\
\hline 2012 & $-5,1$ & $-11,9$ & 1,2 & 10,6 & 17,4 & 18,5 & 22,2 & 19,2 & 14,7 & 8,8 & 4,0 & $-5,9$ & 13.03 .2012 & 12.10 .2012 & $\begin{array}{l}15.01 .2012 \\
\end{array}$ & 58 & 20.04 .2012 \\
\hline 2013 & $-5,5$ & $-1,4$ & $-3,0$ & 9,1 & 18,4 & 21,1 & 19,8 & 18,9 & 12,4 & 8,6 & 5,8 & $-1,0$ & 21.03.2013 & 05.10.2013 & 13.12.2012 & 98 & 20.04 .2013 \\
\hline 2014 & $-6,2$ & $-1,4$ & 5,8 & 9,6 & 16,7 & 17,4 & 21,5 & 19,8 & 13,6 & 5,5 & 1,2 & $-2,7$ & 21.03.2014 & 28.09 .2014 & 09.01 .2014 & 71 & 09.04 .2014 \\
\hline
\end{tabular}

Fig. 1. The results of the WTR periods calculation 
The tables of rainfall intensity and depth of soil freezing estimated values for different zones of the road base were calculated and formed on the basis of the obtained data, (Fig. 2).

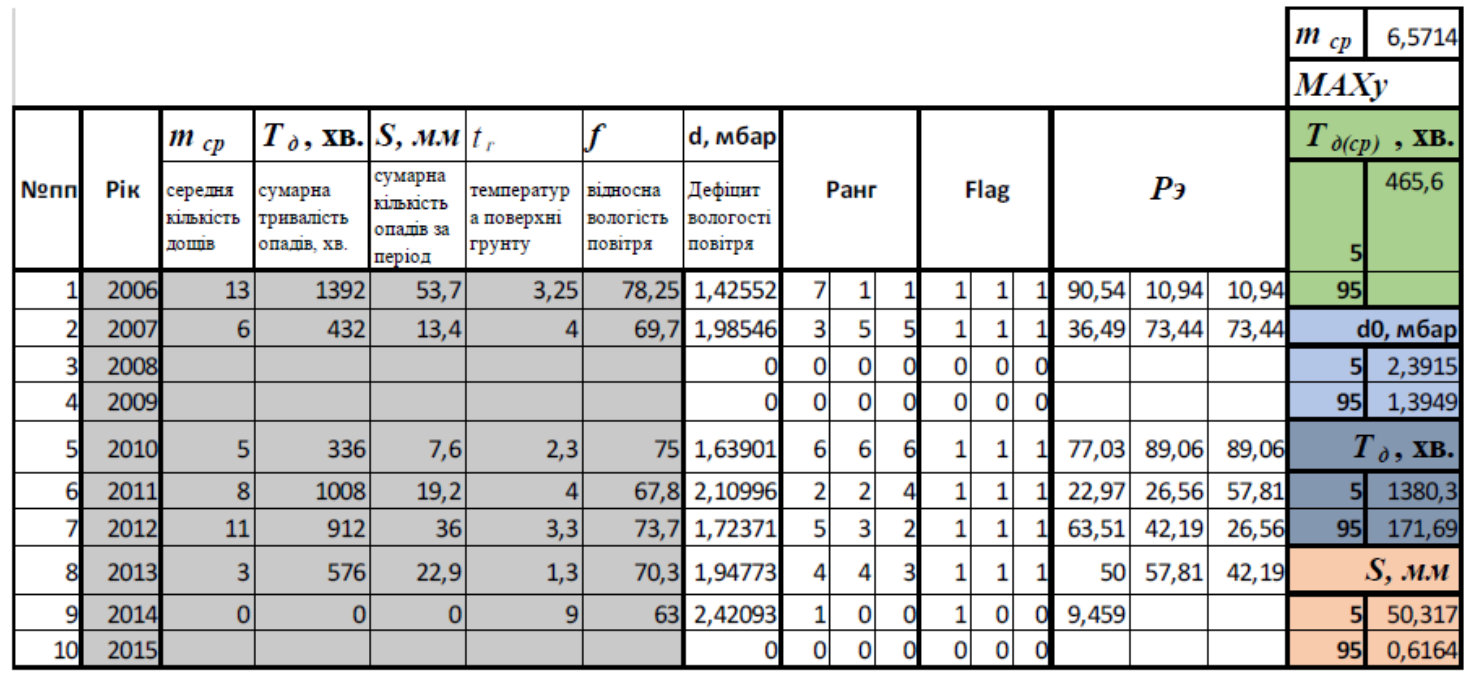

Fig. 2. Calculation of precipitation regime of $5 \%$ security.

The results obtained were used for the climatic zoning of the Ukraine territory. Namely, a cluster analysis tree was built based on the following indicators: average rainfall $5 \%$ security $(\mathrm{mm})$, average monthly temperature in July and average monthly temperature in January. Thus, the necessary climate parameters used in the project practice are covered.

Considering convenience and testing of clustering $[4,5]$, for building a cluster tree the software complex STATISTICA was used to construct the cluster tree. This software is intended for comprehensive statistical analysis. The STATISTICA package implements procedures for data analysis, data management, data retrieval and visualization. It implements the classic methods of cluster analysis, including k-means, hierarchical clustering, and two-input joins. The data can come in the original form as well as in the form of a matrix of distances between objects. Observations and variables can be clustered using different distance measures (Euclidean, Euclidean square, Manhattan, Chebyshev, etc.) and different clustering rules (single, complete, unweighted and weighted pairwise, group average, etc.).

In the case of road-climatic zoning, hierarchical clustering was used. At first, tree diagrams may seem a bit confusing, but after some study they become more understandable. The chart starts from the top (for a vertical dendrogram) with each weather station in its own cluster. When moving down, the weather stations that "closely touch each other" unite and form clusters. Each chart assembly shown in Figure 3, represents a combination of two or more clusters, the position of the nodes on the vertical axis determines the distance at which the corresponding clusters were combined.

As a result of the construction of a cluster analysis tree according to the indicators of average rainfall intensity $5 \%$ - the territory of Ukraine was divided into 3 groups. In group A with the highest average precipitation intensity 5\% (13-15 mm) - Uman, Priluki, Poltava, Melitopol, Kovel, Chernivtsi, Ternopil, Rivne, Lutsk, Chernigov, Ovruch, Lubny, Sumy, Druzhba.

Group B united such meteorological stations as Pervomaysk, Zaporizhia, Melitopol, Simferopol, Kerch, Bolgrad, Kherson, Askania-Nova, Dnepr, Lviv. The average intensity of precipitation according to their data is from 10 to $12 \mathrm{~mm}$.

The group $\mathrm{C}$ includes meteorological stations on a low level of average intensity of precipitation (6-10 mm), as Uzhgorod, Odessa, Nikolaev, Kirovograd, Kharkov, Lugansk, Donetsk, Kiev, Vinnitsa, Khmelnitsky, Zhitomir and White Church.

38 stations of Ukraine were also selected for clustering according to the indices of specific excess moisture entering the drainage structure. The analysis was performed in eight-dimensional space. The main types of regions were identified (Fig. 5).

The results obtained in the STATISTICA software were entered as the source data in the GIS MapInfo software for building a road-climate map. As a result, the above-mentioned indicator was divided into 5 zones, which are not evenly distributed. Their number varies depending on the geographical location of the area (Fig. 6). 


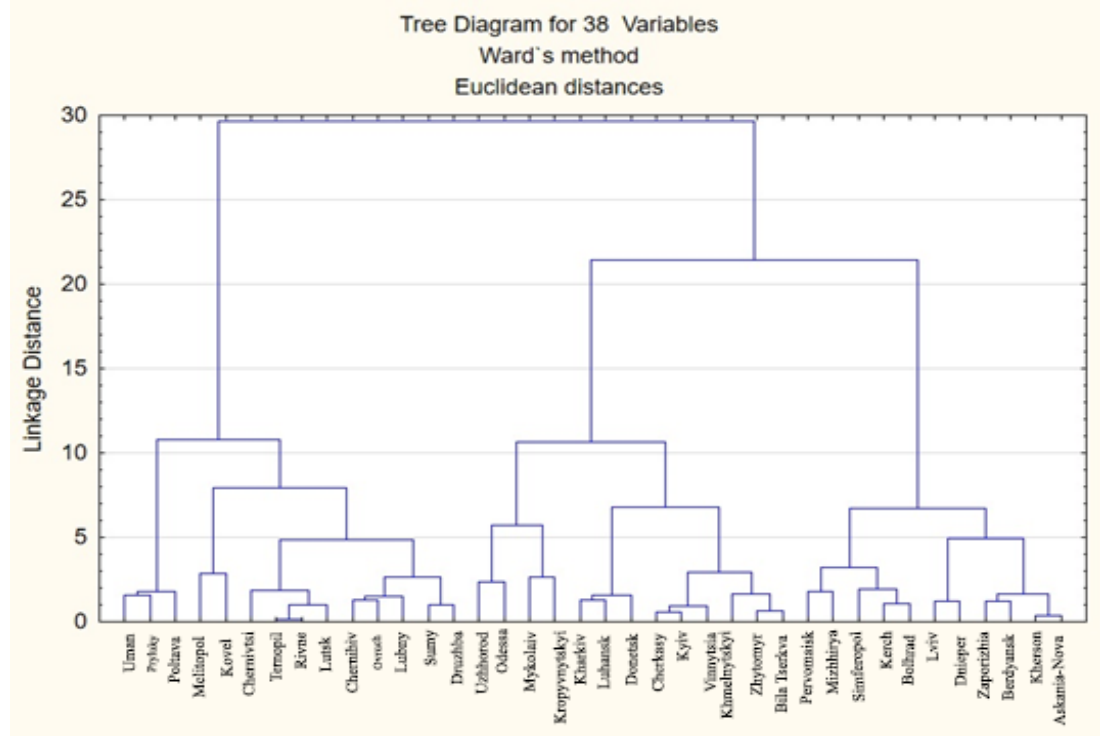

Fig. 3. Cluster tree with average rainfall intensity of 5\% security.

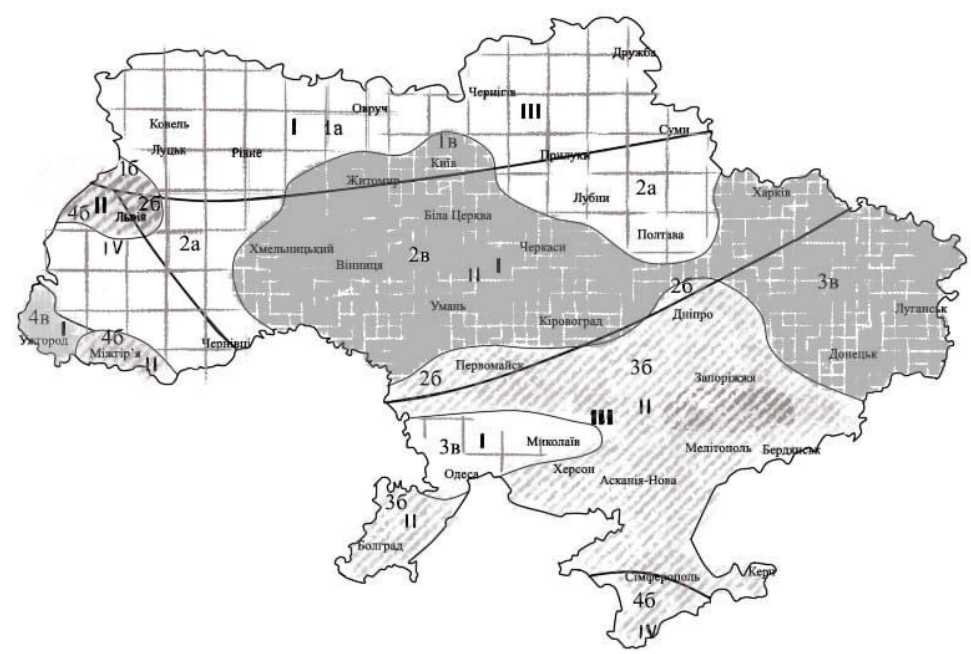

Fig. 4. Map of road-climatic zoning of the Ukraine territory by average rainfall indicators

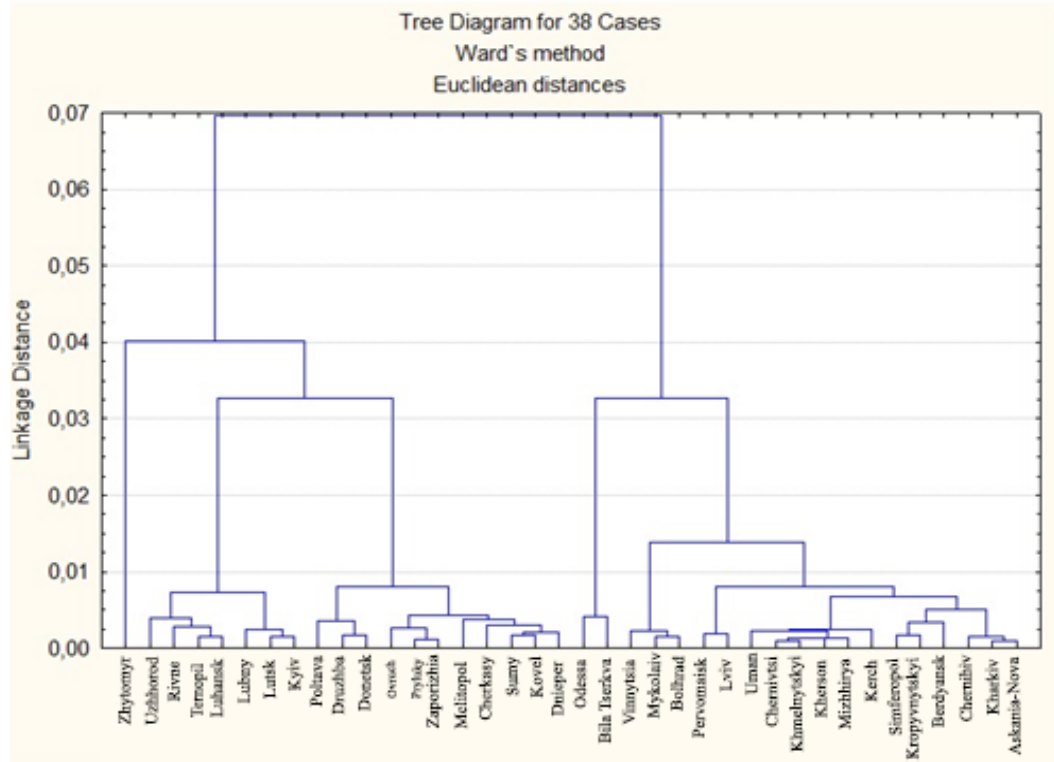

Fig. 5. Cluster tree in terms of specific excess water entering the drainage structure. 


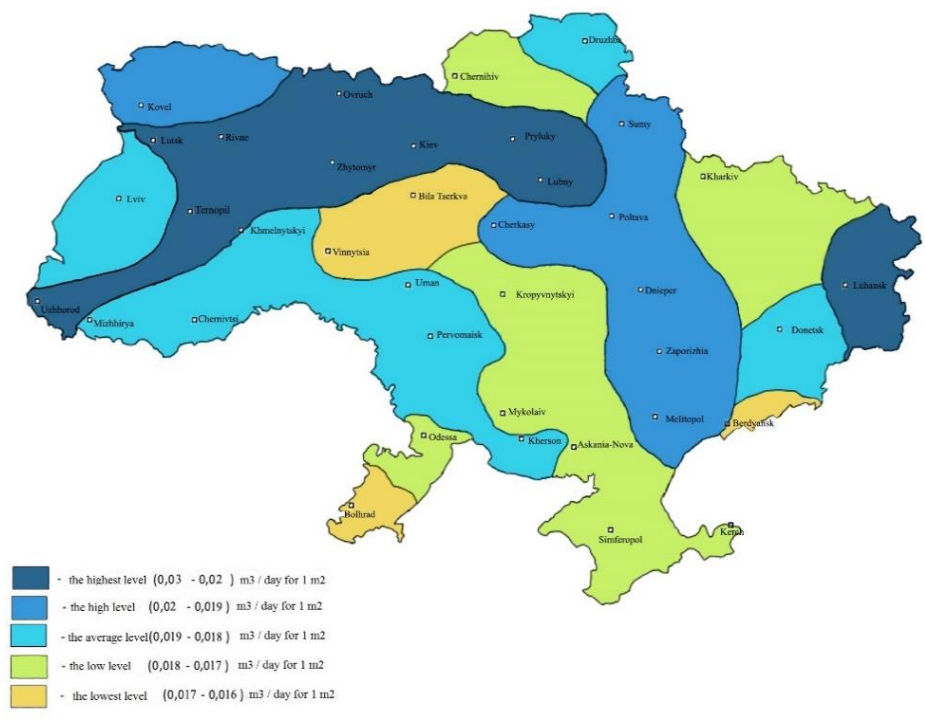

Fig. 6. Map of road-climatic zoning of the Ukraine territory by the specific excess water entering the drainage structure values

Conclusions. Cluster analysis refers to statistical and modeling software systems. Statistical packages have advanced cluster analysis modules to use geographic information to divide objects into groups.

Clustering of territorial units is used for the tipization of the territory and modeling of systemforming connections. On the basis of cluster analysis on the value of specific excess of water entering the drainage structure, a map of road-climatic zoning of the territory of Ukraine was developed in the basis of road clothes. According to the signs of moisture entering the drainage of the shallow construction of the road construction, the territory of Ukraine is divided into 5 zones. On the map of zoning, zones with different levels of total specific excess of water (infiltration and defrosting, from the lowest to the highest level) are allocated. The distribution of zones takes into account both the geographical position of the terrain, and the features of infiltration of atmospheric precipitation, the depth of soil frozen and moisture accumulation in road structures of all technical categories.

On the basis of the result of the work performed - statistical processing and execution of complex calculations, the "Directory of climatic characteristics and climatic zoning of the territory of Ukraine for the regulation of water-heat regime in road construction" was developed. Work is now under way to develop an electronic database of indicators and to develop an improved accounting and analytical system. The purpose of further work is to simplify the use of the obtained indicators and automate the process of designing regulatory structures.

\section{REFERENCES}

1. Juknevičiūtė-Žilinskienè, Lina; Juknevičiūtè-Žilinskienė, Lina (2010) (Lietuvos klimato ịtakos kelių tiesybai vertinimo metodika ir klimatinis rajonavimas) Methodology for the Evaluation of the Effect of the Climate of Lithuania on Road Construction and Climatic Regioning; eLABa - Lithuanian Academic Electronic Library. URL: https://vb.vgtu.lt/object/elaba:1990887/

2. Alfredas Laurinavicius, Lina Jukneviciute-Zilinskiene (2011) Eleven years of rwis operation in Lithuania: possibilities for the use of the data collected the 8th International Conference May 19-20, 2011, Vilnius, Lithuania Selected papers. Vilnius Gediminas Technical University. URL: https://www.researchgate.net/profile/Alfredas_Laurinavicius2/publication/267951476_Eleven_years_of_rwis_oper ation_in_Lithuania_Possibilities_for_the_use_of_the_data_collected/links/54f440390cf299c8d9e6671f.pdf

3. Agnieszka Cupak, Agnieszka Ziernicka-Wojtaszek, Joanna Krużel, Krzysztof Jóźwiakowski, Andrzej Wałęga, Antoni Grzywna, Andrzej Bochniak, Radomir Obroślak, Andrzej Mazur and Artur Serafin (2019) The use of hierarchical cluster analysis for grouping atmospheric precipitation in Poland. The First International Scientific Conference on Ecological and Environmental Engineering 2018 Volume 86, Issue E3S Web Conf. p.8. URL: https://doi.org/10.1051/e3sconf/20198600018

4. Mahfuz, Nurshazwani Muhamad; Yusoff, Marina; Ahmad, Zakiah (2019) Review of single clustering methods IAES International Journal of Artificial Intelligence; Yogyakarta Volume 8, Issue 3, (Sep 2019): 221-227. URL: https://search.proquest.com/openview/6873420c01fed9342ad183704c842ff7/1?pq-origsite=gscholar\&cbl=1686339

5. I.I. Pivovarova (2019) Cluster analysis for structuring spatial data. International Journal of Mechanical Engineering and Technology (IJMET) Volume 10, Issue 02, February 2019, pp. 1085-1109 URL: http://www.iaeme.com/ijmet/issues.asp?JType=IJMET\&VType=10\&IType $=2$

6. DSTU-N B.1.1-27:2010 Building climate science 